\title{
Evaluation of Yield and Yield Related Performance of Cowpea [Vigna unguiculata (L.) Walp] Varieties at West Hararghe Zone, Eastern Ethiopia
}

\author{
Zewdu Asrat*, Temesgen Begna, Abdulfeta Tariku \\ Ethiopian Institute of Agricultural Research, Chiro National Sorghum Research and Training Center P. O. Box \\ 190, Chiro, Ethiopia
}

*Corresponding Authors: Zewdu Asrat, Ethiopian Institute of Agricultural Research, Chiro National Sorghum Research and Training Center P. O. Box 190, Chiro, Ethiopia

\begin{abstract}
Cowpea is an important legume crop growing across the world mainly in tropical and subtropical regions including Ethiopia. However, the production and adoption of cowpea at the study area is mainly constrained by drought and lack of high yielding varieties. Therefore, the experiment was conducted to identify promising and better yielding improved cowpea varieties for drought tolerance related traits. A total of six improved cowpea varieties were evaluated using a randomized complete block design (RCBD) with three replications at Mieso during the main cropping season of 2018 and 2019. The study identified the superior performing cowpea varieties for different studied traits. The combined analyses of variance revealed the presence of tremendous genetic variation among improved cowpea varieties for all the studied traits, which implies the availability of substantial genetic variation among varieties. Overall, White Wonder and Black Eyebean had better performance compared to the other varieties for yield and the yield related traits. White Wonder (1524.66 $\left.\mathrm{kgha}^{-1}\right)$ and Black Eyebean (1235.69 $\mathrm{kgha}^{-1}$ ) varieties recorded the highest grain yield and identified as the superior improved cowpea varieties. Therefore, based on the results of adaptation experiment, White Wonder and Black Eyebean were recommended for production and adoption at Mieso and other similar environments.
\end{abstract}

Keywords: Cowpea; Optimal Performance; Yield; Yields Components

\section{INTRODUCTION}

Cowpea [Vigna unguiculata (L.) Walp; $2 \mathrm{n}=22$ ] is a diploid warm season legume which serves as a major source of calories and protein for many people, especially in developing countries. Cowpea is one of the most important grain legumes in the semi-arid regions of many African countries including Ethiopia. It is grown in the arid and semi-arid regions of the world including Asia, Africa, Asia, Southern Europe and Central and South America. Cowpea used as staple food crops for humans in low income arid regions and also it improves soil amendments (Adams et al., 2018). It also utilized as edible grains, with leaves and green pods when it is fresh before harvest (Ehlers, J.D and Hall, A.E., 1997). Cowpea is a leguminous plant belonging to the Fabaceae family. It is an important grain legume in drier regions and marginal areas of the tropics and sub-tropics. Cowpea is one the most three important subspecies of the species V.unuiculata, which is a widely cultivated grain legume of the world (Onwueme and Sinh, 1991). Grain legumes are the most important family of agricultural crop species after cereals worldwide. In Ethiopia, grain legumes are the most important group of crops providing food to humans, feed to livestock, and income to more than 10 million households. Ethiopia with diverse agro ecology permits different agricultural systems and production of different crops especially grain legumes which are critical to smallholder livelihoods (Kebede, 2020). Among the grain legumes, cowpea is an important food legume growing in tropical and subtropical regions of the world. It is a principal and multipurpose food legume in many African countries including Ethiopia, where tender leaves, fresh pods, and grains are consumed (Alemu et al., 2016).

Cowpea is cultivated primarily in lowland areas of Ethiopia for its edible seeds, pods and leaves. Besides, cowpea provides feed, forage, hay, and silage for livestock, and green manure and cover crop which maintain the productivity of soils (Alemu et al., 2016). In the agricultural system, it 
compensates for the loss of nitrogen absorbed by cereals, thus, it has a positive impact on soil properties. This is due to its unique capacity to fix atmospheric nitrogen and performs well even in poor soils. The crop has also weeds suppressing ability. Being a drought-tolerant and warm-weather crop, it is a promising food and forage species in a typical tropical lowland climate (Alemu et al., 2016; Belay et al., 2017; Bilatu et al., 2012). Cowpea is one of the most preferred crops and a valuable component in the farming systems of the majority of resource poor rural households in SSA for its various attributes (Molosiwa et al., 2016). The crop has the ability to grow under harsh environmental conditions where other major crops fail to grow. Its foliage is regarded as an important source of high-quality livestock feed. In addition, cowpea has the ability to restore soil fertility through nitrogen fixation, making it a good crop to use in crop rotation with major cereal crops (Daryanto et al., 2015).

The bulk of cowpea production and consumption is in sub-Saharan Africa, especially in the SudanoSahelian Zone (Boukar et al., 2019). About 95\% of global production reported in FAOSTAT is in West Africa, with Nigeria being the largest producer and consumer of cowpea, producing 3.4 million tons in 2017 (FAOSTAT, 2017; Samireddypalle et al., 2017). Most of the production in sub-Saharan Africa is by smallholder farmers in marginal conditions, often as an intercrop with maize, sorghum, or millet (Ehlers and Hall, 1997). Due to its high adaptability to both heat and drought and its association with nitrogen-fixing bacteria, cowpea is a versatile crop (Boukar et al., 2019). Almost the entire aerial section of the cowpea plant is edible and regularly consumed. The fresh grains are often consumed during the harvest season, and immature pods are eaten as a vegetable, especially in Southeast Asia. In addition, the tender leaves are consumed as a pot herb, mostly in East Africa (Boukar et al., 2019). The dry haulms are harvested and sold as fodder for livestock (Samireddypalle et al., 2017). Beyond direct consumption, cowpea provides important agronomic services. As a legume, the plants form root nodules in cooperation with nitrogen-fixing bacteria and are used as green manure (Fatokun et al., 2002). Spreading varieties are also utilized as cover crops to prevent soil erosion and reduce the incidence of weeds (Wortman and Dawson, 2015). Cowpea is a valuable species for cultivation as the effects of global climate change become more pronounced.

Regions where cowpea is highly cultivated, such as sub-Saharan Africa, overlap with areas predicted to suffer from increased food insecurity due to climate change. Among the expected effects are more extreme weather events, including deeper and longer droughts and increased heat. Cowpea is wellsuited for targeted breeding efforts addressing drought and heat tolerance as it produces high yields under terminal drought conditions, is heat resistant, and requires less water than other commonly cultivated legume species (Agbicodo et al., 2009). As a food crop, cowpea is an excellent source of protein, fiber, and a wide range of micronutrients. Cowpea grains are $20-30 \%$ protein by dry weight (Boukar et al., 2011), and the leaves have a similar protein content. In addition, cowpea is a good source of folic acid, a nutrient of particular importance for pregnant women, and other micronutrients (Boukar et al., 2011). Cow pea is an important food for human being, it also provide feed, forage, hay and silage for livestock and green manure and cover crop for maintaining the productivity of soils. When intercrop with cereals, it compensates for the loss of nitrogen removed by cereals. It is also a good cover crop to restrict soil erosion (Onwueme and Sinha, 1991). Cow pea is drought tolerant annual crop in condition where moisture deficiency has less effect on seed formation. It grows with less rain fall and under more adverse condition. The grains are good source of human protein, while the haulms are valuable source of livestock protein (Fatokum, 2002).

It is the second most important food grain legume crop in tropical Africa, next to Phaseolus vulgaris, the common bean (Belay et al., 2017). Cowpea is a warm-weather crop with somewhat higher temperature requirement than maize. Cowpea is drought tolerant annual crop in condition where moisture deficiency has less effect on seed formation. It grows with less rainfall and under more adverse condition than haricot bean. Like other leguminous crops, it is also grown for improving soil fertility (Tesema and Eshetayehu, 2006). Cowpea withstands heat better than most other legumes do. Cowpea can be grown in a wide variety of soils, but yields better on well-drained soils with medium fertility (Belay et al., 2017). Cowpea is produced in Ethiopia primarily for its edible seeds, pods and the leaves that are used as human food and animal feed, and income provision to households. Its production is practiced under varying cropping systems including sole cropping, intercropping and mixed cropping system. Despite its versatility and economic value for the lives of lots of subsistence 
farmers, the national mean yield of cowpea in Ethiopia is estimated to be $0.4 \mathrm{t} \mathrm{ha}^{-1}$ (Beshir et al ., 2019 ) while the yield potential of cowpea averaged 1.5 to $6 \mathrm{t} \mathrm{ha}^{-1}$ depending on genotype (Asiwe et al . , 2008). Therefore, there is a large gap among the actual and potential yield of a crop; and hence this calls for research interventions. Constraints that cause low cowpea yields include lack of suitable varieties for farmers needs, a biotic stresses (drought, low soil fertility) and biotic stresses like pests, diseases, poor agronomic practice and limited research work (Yoseph T, 2014).

Early maturity and moderate degree of drought tolerance led the crop's vital role in farmers' strategies for risk aversion in drought prone lowland areas of the country (Mekonnen, F, 2007). However, yield per unit area is very low particularly, in Mieso, Eastern Ethiopia. However, Ethiopia has a high potential for the production of various crops, especially cowpea, due to the diverse agro-ecology and suitability of the country. Moreover, the integration of cowpea with the farming system has significant importance in improving yields, nutrition, soil productivity, feed quality, and withstands the impact of climate change. Therefore, further research strategies, development of high yielder varieties, promotion of improved agronomic practices and successful marketing systems are required to alleviate problems and boost the production of cowpea in Ethiopia. Therefore, this study was intended to evaluate and select suitable improved cowpea variety/varieties for their yielding ability in the moisture stressed areas of west Harerghe, Eastern Ethiopia.

\section{Materials AND Methods}

\section{Description of the Experimental Area}

The field experiment was conducted under rain-fed conditions at Mieso Agricultural Sub- Research station during the 2018 and 2019 main cropping seasons. Mieso is located 302 kilometers away in the eastern from Addis Ababa, the capital city of Ethiopia in Oromia regional state. Its elevation is 1470 metres above sea level and is located at $8^{\circ} 30^{\prime} \mathrm{N}$ latitude and $39^{\circ} 21^{\prime} \mathrm{E}$ longitudes and with having an average maximum and minimum temperatures of $14.0^{\circ} \mathrm{C}$ and $30.01^{\circ} \mathrm{C}$ and with an average annual rainfall $763 \mathrm{~mm}$. The dominant soil type is Vertisols with $\mathrm{p}^{\mathrm{H}} 5.4$ (Lemma, 2008).

\section{Treatments and Experimental Procedures}

A recently released six improved cowpea varieties were used for the experiment. The improved lowland cowpea varieties were released for lowland agro-ecologies by the national lowland pulse improvement program in different times. These varieties were planted under field conditions in a randomized complete block design (RCBD) with three replication. The plot size was $4 \times 3.2 \mathrm{~m}$ $\left(12.8 \mathrm{~m}^{2}\right)$ having 8 rows with harvestable plot area of $1.6 \times 4 \mathrm{~m}\left(6.4 \mathrm{~m}^{2}\right)$ with four rows and spacing $40 \mathrm{~cm}$ between rows and $10 \mathrm{~cm}$ between plants was maintained. The spacing between replication, blocks and plots within each block was $1.50,1$ and $0.50 \mathrm{~m}$, respectively. Di-ammonium phosphate (DAP) fertilizer and urea were applied at a rate of $100 \mathrm{~kg} \mathrm{ha}^{-1}$ and $50 \mathrm{~kg}^{-1}$ respectively at planting. Weeds were controlled periodically by hand weeding and other management practices like pest or disease-control was done as required.

Table1. Description of the experimental materials

\begin{tabular}{|l|l|l|l|l|}
\hline S.No & Variety & Agro-ecology & Status & Source \\
\hline 1 & Black Eyebean & Lowland & Released Variety & Melkasa ARC \\
\hline 2 & Asebot & Lowland & Released Variety & Melkasa ARC \\
\hline 3 & WWT & Lowland & Released Variety & Melkasa ARC \\
\hline 4 & White Wonder & Lowland & Released Variety & Melkasa ARC \\
\hline 5 & Bole & Lowland & Released Variety & Melkasa ARC \\
\hline 6 & Kenkenti & Lowland & Released Variety & Melkasa ARC \\
\hline
\end{tabular}

\section{Data Collection}

Data were collected on plant and plot basis for different agronomic traits. These data of days to flowering stand at harvest, days to maturity; plant height and yield were recorded during experimentation. Days to flowering 
was recorded as the number of days form emergence to when $50 \%$ of the plants had flowered in a plot. Days to $90 \%$ maturity was the number of days from emergence to the stage when $90 \%$ of the plants in a plot have reached physiological maturity; stand count at harvest was counted on a plot before harvesting the pods and grain yield was recorded from the four central rows of each plot.

\section{Data Analysis}

The data were analyzed using PROC ANOVA in SAS software version 9.4 (SAS, 2018) and means were separated using Fisher's Least Significant Difference (LSD) test at 5\% level of probability as stated in Gomez and Gomez (1984).

\section{RESULTS AND DISCUSSION}

\section{Analysis of Variance for Yield and Yield Related Traits}

The combined analysis of variance showed that varieties performed significantly differently for all the phenological and growth traits (days to 50\% flowering, stand count at harvest, Days to $90 \%$ maturity, plant height $(\mathrm{cm})$ and yield $(\mathrm{kg})($ Table-2). Presence of significant difference among cowpea varieties for the studied traits ensured the presence of substantial genetic variation to be improved through selection. There was very highly significant difference observed for days to maturity and highly significant difference was observed for days to flowering and stand at harvest. There was also significant difference in plant height and yield $\mathrm{kg}^{-1}$ among tested genotypes. This indicated the presence of considerable variation in the genetic materials for these traits and there is a possibility to improve the investigated cowpea varieties with simple selection. Plant breeding is primarily depending on presence of substantial genetic variation to address the maximum genetic yield potential of the crops and simple selection can be effective to make further improvement when the genetic variation is available among the studied varieties. Hence, the obtained results encourage the presence of substantial genetic variation among varieties for the major studied traits.

Table2. Means Squares from Analysis of Variance for Six Observed Characters

\begin{tabular}{|l|l|l|l|l|l|}
\hline Source of Variation & DTF & DTM & SH & PHT & GY \\
\hline Replication & 1.72 & 21.06 & 0.32 & 0.09 & 2722 \\
\hline Genotypes & $127.42^{* *}$ & $111.56^{* * *}$ & $47.39^{* *}$ & $73.60^{*}$ & $396663^{*}$ \\
\hline Residuals & 16.813 & 6.691 & 7.31 & 17.999 & 120624 \\
\hline
\end{tabular}

***Very highly significant at $0.1 \%$ probability level, **highly significant at $1 \%$ probability level, $*$ highly significant at $5 \%$ probability, $n s=$ non-significant at $5 \%$ probability level where, DTF $=$ days to $50 \%$ flowering, DTM=days $90 \%$ to physiological maturity, SH=stand count at harvest, PHT=plant height, GY= grain yield.

\section{Mean Performance of cowpea Genotypes for Yield and Yield Related Traits}

Yield improvement is the primary concern of plant breeders to mitigate the effect of food security problems. Nowadays, the development of the superior genotypes in terms of yield and other many different traits very critical to address the required challenges of human population growth and climate change. Overcoming these difficult challenges will be harder in the absence of plant genetic improvement to increase agricultural productivity through addressing the problem of yield reduction and its links with pest management and climate change. Based on the mean performance, the superior cowpea genotypes were identified for different traits as indicated in (Table-3). Interestingly, the maximum grain yield was obtained from White Wonder (1524.66 kgha-1) followed by Black Eyebean $\left(1235.69 \mathrm{kgha}^{-1}\right)$. This revealed the yield performance of the White Wonder variety was highest as compared to the rest tested varieties. This showed the improved lowland cowpea varieties had better adaptation and yield advantages at moisture stressed areas.

Kenkenti variety flowered (46 days) and matured (78.3) earlier whereas the high yielder White Wonder flowed (62.67 days) and matured (95.67 days) late. Days to flowering and maturity are among the most important characteristics that need to be considered in selecting varieties when and where the shortage of rainfall is limiting factor for further improvement of yield and yield related traits. 
Evaluation of Yield and Yield Related Performance of Cowpea [Vigna unguiculata (L.) Walp] Varieties at West Hararghe Zone, Eastern Ethiopia

However, early maturing varieties have been shown low yield whereas the late mature varieties have shown high yield. Hence, the yield performance the varieties were not directly correlated to improved though simple selection and suggested to search for another breeding procedures to improve the yield and maturity of varieties for drought tolerance.

Table3. Mean Performance of Six Cowpea Varieties Evaluated For Six Agronomic and Yield Characters

\begin{tabular}{|l|l|l|l|l|l|}
\hline Genotypes & DF & DM & SH & PHT & YLD \\
\hline Black Eyebean & $62.67^{\mathrm{ab}}$ & $95.67^{\mathrm{a}}$ & $52^{\mathrm{ab}}$ & $64.67^{\mathrm{a}}$ & $1235.69^{\mathrm{ab}}$ \\
\hline Asebot & $55 \mathrm{ab}$ & $87.67^{\mathrm{ab}}$ & $44.33^{\mathrm{bc}}$ & $44.67^{\mathrm{c}}$ & $695.05^{\mathrm{cd}}$ \\
\hline White wonder & $54.67^{\mathrm{b}}$ & $97.67^{\mathrm{a}}$ & $54^{\mathrm{a}}$ & $63.67^{\mathrm{a}}$ & $1524.66^{\mathrm{ab}}$ \\
\hline Bole & $44.33^{\mathrm{c}}$ & $83.67^{\mathrm{bc}}$ & $44.67^{\mathrm{bc}}$ & $52^{\mathrm{abc}}$ & $631.913^{\mathrm{cd}}$ \\
\hline Kenkenti & $46^{\mathrm{c}}$ & $78.3^{\mathrm{bc}}$ & $48.33^{\mathrm{ab}}$ & $57^{\mathrm{ab}}$ & $786.08^{\mathrm{bc}}$ \\
\hline CV \% & 6.03 & 3.84 & 7.4 & 9.24 & 14.82 \\
\hline LSD 0.05 & 7.93 & 9.16 & 6.92 & 12.5 & 450.86 \\
\hline
\end{tabular}

Note: Means in a column with the same letter (s) are not significantly different by LSD's test $(P=0.05)$, $D T F=$ days to $50 \%$ flowering, DTM=days to physiological maturity, SH=stand count at harvest, PHT=plant height, $G Y=$ grain yield, $L S D=$ Least significance difference, $C V(\%)=$ Coefficient of variation in percent.

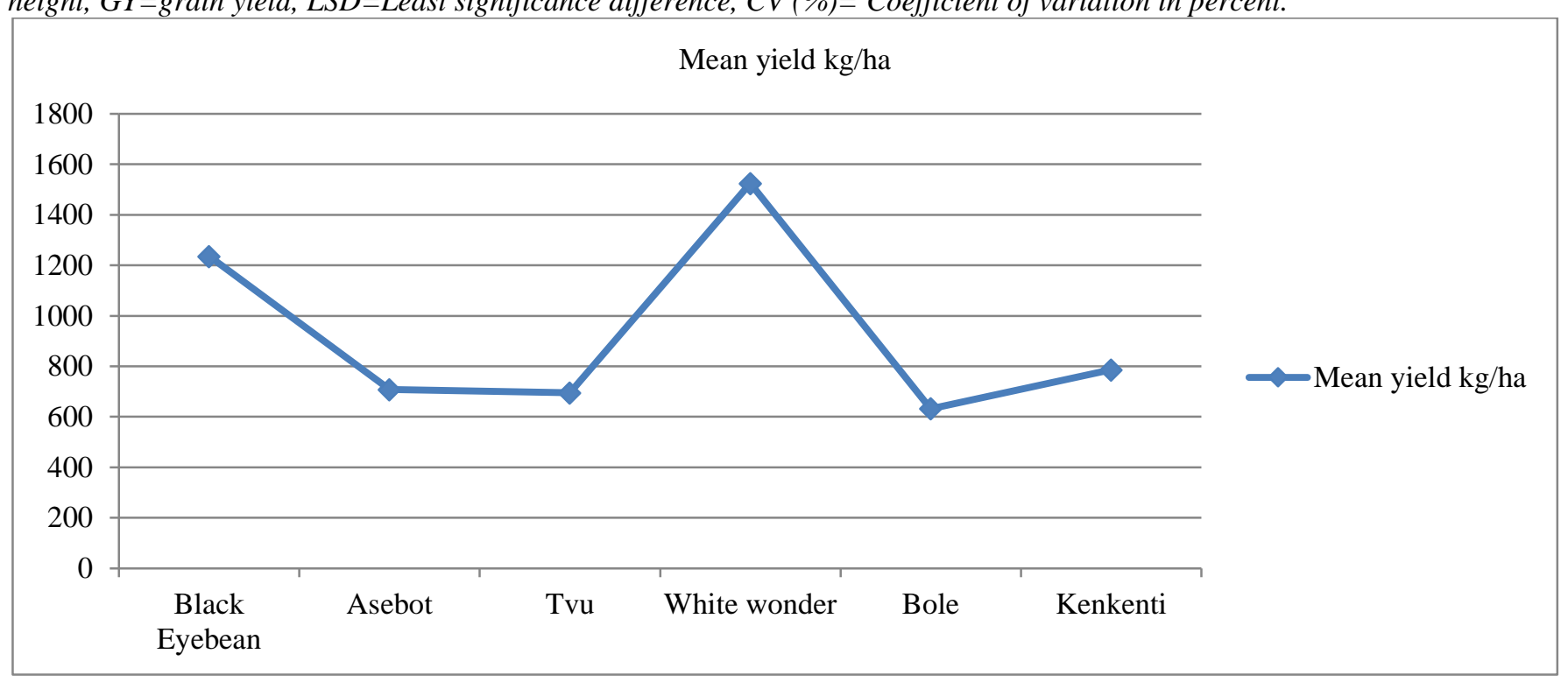

$\mathrm{F}$

Figure1. The mean yield performance of six cowpea varieties in study area

\section{CONCLUSION}

Cowpea is the most important drought resilient food crop for drought prone areas especially lowland parts of Ethiopia. The present investigation revealed the presence of genetic variability among genotypes with respect to different traits. The presence of significant difference among sorghum genotypes for the studied traits ensured the presence of large genetic variation to be improved through selection. The presence of considerable variation in the genetic materials implied that the possibility to improve the genotypes with simple selection for the studied traits. Plant breeding is primarily depends on presence of substantial genetic variation to address the maximum genetic yield potential of the crops and exploitation of these variations through effective selection for further improvement. This significant genetic variation among genotypes suggested that the genotypes were genetically diverse and it could be a good opportunity for breeders to select genotypes for trait of interest for variety development. Hence, the obtained results encourage the availabilities of substantial genetic variation among genotypes for the major studied traits. The potential cowpea varieties identified based on the superior mean yield performance and other related traits.

Analysis of variance showed highly significant varietal differences at $\mathrm{P} \leq 0.01$ for days to $50 \%$ flowering; stand count at harvest and very highly significant difference at $\mathrm{P} \leq 0.001$ days to $90 \%$ maturity whereas significant difference was observed for plant height, and grain yield at $\mathrm{P} \leq 0.001$ 
probability level. The combined means result indicated that the White Wonder $\left(1524.66 \mathrm{kgha}^{-1}\right)$ and Black Eyebean (1235.69 $\left.\mathrm{kgha}^{-1}\right)$ cowpea varieties had the highest yield respectively. The earliness trait (days to flowering and days to physiological maturity) enables them to flower and mature early, therefore escaping from moisture stress, the most important drought factors that results in reduced yield. As compared to the others, White Wonder and Black Eyebean were therefore recommended as promising varieties to the farmers of Mieso area and other districts having the same agro-ecologies based on their optimal yield performance for adoption.

\section{ACKNOWLEDGMENTS}

The authors acknowledged Ethiopian Institute of Agricultural Research (EIAR), Chiro National Sorghum Research and Training Center and Melkasa Agricultural Research Center (National lowland pulse improvement program) for supporting and funding the activity during field experimentation.

\section{REFERENCES}

[1] Adam, F.M and Lawan, H.K., Badau, M.H., Chibuzo, E.C., 2018. Proximate composition, antinutrient factors and functional properties of complementary food formulations as affected by sorghum processing methods, addition of cowpea and carrot. International Journal of Food Science and Nutrition, 3(2), pp.14554.

[2] Agbicodo, E.M., Fatokun, C.A., Muranaka, S. and Visser, R.G., 2009. Breeding drought tolerant cowpea: constraints, accomplishments, and future prospects. Euphytica, 167(3), pp.353-370.

[3] Alemu, M., Asfaw, Z., Woldu, Z., Fenta, B.A. and Medvecky, B., 2016. Cowpea (Vigna unguiculata (L.) Walp.)(Fabaceae) landrace diversity in northern Ethiopia. International Journal of Biodiversity and Conservation, 8(11), pp.297-309.

[4] Asiwe, J.A.N., Moala, I., Funnah, S.M. and Odu, B. (2008). Introduction and evaluation of germplasm for genetic enhancement of cowpea in South Africa. Proceedings. Combined conference of South African Society of Crop Production and Soil Science Society of South Africa, 21-25 January, 2008, Grahamstown, South Africa

[5] Belay F, Meresa H (2017). Performance evaluation of sorghum [Sorghum bicolor (L.) Moench] hybrids in the moisture stress conditions of Abergelle District, Northern Ethiopia. J. Cer. Oilseeds 8(4):26-32.

[6] Belay, F., Gebreslasie, A. and Meresa, H., 2017. Agronomic performance evaluation of cowpea [Vigna unguiculata (L.) Walp] varieties in Abergelle District, Northern Ethiopia. Journal of Plant Breeding and Crop Science, 9(8), pp.139-143.

[7] Beshir, B., Amsalu, B., Dagmawit, T., Selamawit, K., Teamir, M., \& Bezawit, Y. (2019). Cowpea production, marketing and utilization in Ethiopia (Research Report 121). Ethiopian Institute of Agricultural Research. http://hdl.handle.net/123456789/3222

[8] Bilatu A, Binyam K, Solomon Z, Eskinder A, Ferede A (2012). Animal feed potential and adaptability of some cowpea (Vigna unguiculata) varieties in Northwest lowlands of Ethiopia. Wudpecker J. Agric. Res. 1(11): 478-483.

[9] Boukar, O., Belko, N., Chamarthi, S., Togola, A., Batieno, J., Owusu, E., Haruna, M., Diallo, S., Umar, M.L., Olufajo, O. and Fatokun, C., 2019. Cowpea (Vigna unguiculata): Genetics, genomics and breeding. Plant Breeding, 138(4), pp.415-424.

[10] Boukar, O., Massawe, F., Muranaka, S., Franco, J., Maziya-Dixon, B., Singh, B. and Fatokun, C., 2011. Evaluation of cowpea germplasm lines for protein and mineral concentrations in grains. Plant Genetic Resources, 9(4), pp.515-522.

[11] Daryanto, S., Wang, L. and Jacinthe, P.A., 2015. Global synthesis of drought effects on food legume production. PloS one, 10(6), p.e0127401.

[12] Ehlers, J.D. and Hall, A.E., 1997. Cowpea (Vigna unguiculata L. walp.). Field crops research, 53(1-3), pp.187-204.

[13] FAO (Food and Agricultural Organisation). (2017). FAOSTAT online statistical services: Crop production data. Food and Agriculture Organization of the United Nation (FAO), Rome. Available at: http://www.fao.org/faostat/en/\#data/QC. Accessed August 24, 2017. 
[14] Fatokum AC (2002). Breeding cow pea for resistance to insect pests, International Institute of Tropical Agriculture (IITA), Ibadan, Nigeria, pp. 52-61.

[15] Gomez AA, Gomez KA. (1984). Statistical procedures for agricultural research, 2nd edition. John wiley and Sons Inc., New York.

[16] Kebede, E., 2020. Grain legumes production and productivity in Ethiopian smallholder agricultural system, contribution to livelihoods and the way forward. Cogent Food \& Agriculture, 6(1), p.1722353.

[17] Lemma, W., 2008. Physicochemical studies of soils of Miesso areas, Eastern Hararghe, Oromia region (Doctoral dissertation, MSc Thesis presented to the School of Graduate Studies of Haramaya University. Haramaya, Ethiopia).

[18] Mekonnen, F., 2007, September. Haricot ban (Phaseolus Vulgaris L.) variety development in the lowland areas of Wollo. In Conference on Completed Crops Research Activities.

[19] Molosiwa, O.O., Gwafila, C., Makore, J. and Chite, S.M., 2016. Phenotypic variation in cowpea (Vigna unguiculata [L.] Walp.) Germplasm collection from Botswana. International Journal of Biodiversity and Conservation, 8(7), pp.153-163.

[20] Onwueme IC, Sinha TD (1991). Field Crop Production in Tropical Africa. Principles and practice. CTA, Wageningen, Netherlands.pp.324-336.

[21] Samireddypalle, A., Boukar, O., Grings, E., Fatokun, C.A., Kodukula, P., Devulapalli, R., Okike, I. and Blümmel, M., 2017. Cowpea and groundnut haulms fodder trading and its lessons for multidimensional cowpea improvement for mixed crop livestock systems in West Africa. Frontiers in plant science, 8, p.30.

[22] SAS Institute Inc (2018). SAS /STAT users guide. Version 9.4, 4th edition. Cat, NC.

[23] Tesema T and Eshetayehu T (2006). Collection, Conservation, Characterization and Sustainable Utilization of Grain Legumes in Ethiopia. Proceedings of the workshop on food and forage legumes 22-26 September 2003, Addis Ababa, Ethiopia. pp. 15-22.

[24] Wortman, S.E. and Dawson, J.O., 2015. Nitrogenase activity and nodule biomass of cowpea (Vigna unguiculata L. Walp.) decrease in cover crop mixtures. Communications in Soil Science and Plant Analysis, 46(11), pp.1443-1457.

[25] Yoseph Tekle. (2014). Performance Evaluation of Cowpea (Vigna unguiculata L.) Varieties under Moisture Conservation Practices for Yield and Yield Components at Alduba, Southern Ethiopia.https://www.iiste.org/Journals/index.php/JNSR/article/download/12556/1292

Citation: Zewdu Asrat.et.al.,, (2021). "Evaluation of Yield and Yield Related Performance of Cowpea [Vigna unguiculata (L.) Walp] Varieties at West Hararghe Zone, Eastern Ethiopia”, International Journal of Research Studies in Agricultural Sciences (IJRSAS), 7(7), pp. 42-48 DOI: http://dx.doi.org/ 10.20431/2454-6224.0707005

Copyright: () 2021 Authors. This is an open-access article distributed under the terms of the Creative Commons Attribution License, which permits unrestricted use, distribution, and reproduction in any medium, provided the original author and source are credited. 